Arq. Bras. Med. Vet. Zootec., v.70, n.4, p.1301-1308, 2018

\title{
Analysis of the effects of climate variables on Apis mellifera pollen foraging performance
}

\author{
[Análise dos efeitos de variáveis climáticas no desempenho de forrageamento de pólen \\ de abelhas Apis mellifera] \\ I.M. de Mattos $^{1,2}$, J. Souza ${ }^{1}$, A.E.E. Soares ${ }^{1}$ \\ ${ }^{1}$ Faculdade de Medicina de Ribeirão Preto, Universidade de São Paulo - Ribeirão Preto, SP \\ ${ }^{2}$ The Hebrew University of Jerusalem - Jerusalem, Israel
}

\begin{abstract}
Pollination services performed by bees are essential for the reproduction of a great part of flowering plants. The pollen collected by Apis mellifera while performing pollination (bee pollen), has been incorporated into the human diet for its favorable nutritional components. Around 1,500 tons of bee pollen are produced annually worldwide, especially in Spain, China, Australia, Argentina, and Brazil. Despite the importance of bee pollen within apiculture, little is known about the effects of climate variations on bee pollen collection and production. We monitored the pollen collection performance of 24 different honey bee colonies in different climate conditions within a period of one year. We then analyzed the statistical interaction among the number of worker bees returning with pollen loads and 12 climatic variables, to produce a predictive mixed linear model. The results obtained showed that 7 climatic variables were statistically correlated to the pollen collection observed: Maximum temperature of the day, minimum temperature of the day, dew point temperature, relative humidity, cloud cover, rainfall, and the date of the sample. This research brings information for the development of a more effective pollen productive system.
\end{abstract}

Keywords: africanized honey bees, bee pollen, climate, foraging, pollination

\section{RESUMO}

Serviços de polinização são essenciais para a reprodução de uma grande parte das plantas com flores. Além de fundamental para produtividade agrícola e segurança alimentar no planeta, a atividade de polinização por Apis mellifera também possibilita a produção do pólen apícola. Devido a sua riqueza nutricional, o pólen apícola vem sendo incorporado às dietas humanas e de animais de interesse zootécnico. Cerca de 1.500 toneladas de pólen de abelha são produzidas anualmente em todo o mundo, especialmente em países como Espanha, China, Austrália, Argentina e Brasil. Apesar da importância do pólen na cadeia produtiva apícola, muito pouco se conhece sobre os efeitos das variações climáticas sobre a coleta e a produtividade de pólen. Neste estudo, foi monitorado o desempenho da coleta de pólen de 24 colonias de abelhas africanizadas, em diferentes condições climáticas, por um período de um ano. Analisaram-se estatisticamente as interações dos dados obtidos para o número de abelhas operárias que retornaram com cargas de pólen nas corbículas e 12 variáveis climáticas, a fim de se produzir um modelo estatístico preditivo. Os resultados obtidos mostraram que sete variáveis climáticas influenciaram significativamente a coleta de pólen: temperatura máxima do dia, temperatura mínima do dia, temperatura do ponto de orvalho, umidade relativa, cobertura de nuvens, precipitação pluviométrica e data da amostragem. Esta pesquisa traz informações importantes para o desenvolvimento de um sistema produtivo de pólen apícola mais eficaz.

Palavras-chave: abelhas africanizadas, pólen apícola, clima, forrageamento, polinização

\section{INTRODUCTION}

Today more than 83 million beehives are kept worldwide (FAOSTAT, 2014). Honey is, for sure, the most consecrated bee product, but it is not the only one, and it is not the most important

Recebido em 2 de fevereiro de 2017

Aceito em 25 de agosto de 2017

E-mail: igor.medicide@mail.huji.ac.il
(Cvitkovi et al., 2009). Pollination services performed by wild and kept bees are essential for the reproduction of a great part of flowering plants, once pollination promotes a more effective transference of genes among populations of wild and cultivated plant species (Kearns et al., 1998). The importance of insect 
pollination has been valued at over $€ 153$ billion, annually, for agricultural production (Gallai et al., 2009). The pollen collected and transferred among different flowers (pollination) promotes plant reproduction and, as a mutualistic relationship, provides bees the collected surplus pollen as a nutritional resource for protein, lipids, and antioxidant substances (Campos et al., 2010). For its nutritional richness, the pollen collected by Apis mellifera while performing pollination has been incorporated into the human diet (FAO, 2009). Around 1,500 tons of bee pollen are produced annually worldwide, especially in Spain, China, Australia, Argentina, and Brazil (FAO 2009). Despite the importance of bee pollen within apiculture, many aspects of bee pollen production remain without the deserved attention of science (de Mattos et al., 2016). Thus, there is no standard protocol concerning the most suitable techniques to be applied in the bee pollen production system as well as limited knowledge related to the effects of climate variations on bee pollen collection.

Climatic conditions seem to strongly affect insects, once the variations are capable of impacting behavior, physiology and reproductive success of those animals (Brown and Paxton, 2009). The climate is also able to produce significant effects on plant's phenology, including pollen and nectar (Tooke and Battey, 2010). For that reason, this study aimed to analyze the effects of climate on pollen foraging for the better understanding of what kind of climatic variables are influent on bee pollen production. Studies able to obtain information about such effects are an important tool for the development of a more effective bee pollen productive system.

\section{MATERIAL AND METHODS}

The study was conducted at the University of São Paulo (USP) apiary in Ribeirão Preto - SP, Southeastern Brazil (21 $10^{\prime} 42^{\prime \prime} \mathrm{S}, 47^{\circ} 48^{\prime} 24^{\prime \prime}$ W, height: $545 \mathrm{~m})$. The apiary was settled in an area surrounded by Eucalyptus sp abandoned crop and native vegetation. According to the classification system developed by Köppen and Geiger (1928), the region presents a subtropical climate, ranging from humid to sub-humid. The climate of the region is typically defined by two marked seasons: one cool and dry (April to
September) and another hot and rainy (October to March) (Silva et al., 2014).

For 12 consecutive months (January to December 2014) we monitored the pollen foraging activities in 24 colonies kept in standard Langstroth hives. All the studied colonies had approximately the same population size by the beginning of the study (composed by eight brood frames and two food frames, with bees covering 8 of the 10 frames). All colonies were headed by siblings Africanized honey bee queens of the same age. We observed and recorded (using a hand counter) the number of worker bees returning with pollen loads on their corbiculas, during a period of 3 minutes per day, in each one of the tested colonies. All the observations started at 7:30am, from January to December of 2014. We adjusted the observations during the Brazilian daylight saving time to maintain the same starting hour throughout the year. Twelve climatic variables (independent variable) were daily recorded for further statistical analysis (Table 1). The date of the observation was also analyzed as a variable. For that propose, the sampling dates were converted into ordinal numbers by a count up of the days of the year (January $1^{\text {st }}$ as the day 1 and December $31^{\text {st }}$ as the day 365 ). The climatic data were obtained in two databases provided by the Brazilian government and the São Paulo State government (respectively: Instituto Nacional de Pesquisas Espaciais - INPE: http://www.inpe.br/; and Centro Integrado de Informações Agrometeorológicas - $\quad$ CIIAGRO: http://www.ciiagro.org.br/). Both databases registered climatic variables from the nearest meteorological station to the apiary (approximately $5 \mathrm{~km}$ away).

The statistical modeling of the data concerning pollen collection and climatic variables were done using generalized linear mixed models. The number of worker bees, returning with pollen loads, was used as the dependent variable and the other 12 climatic data as the independent variables. In order to account the response of individual colonies over time, we included a random intercept for each colony and a random slope, as described in Koffler et al. (2015). All continuous variables were centered and scaled to aid model convergence. All statistical procedures were done on SAS (2004). 


\section{RESULTS}

The number of foragers per colony collecting pollen ranged from 0 to 443 (during the 3 minutes of observation), with a mean of 69.69 (S.D. \pm 56.31). Temperatures varied from 10.90 to $39.00^{\circ} \mathrm{C}$, relative humidity varied from 22 to $100 \%$, cloud cover from 0 to $100 \%$, rainfall from 0 to $23 \mathrm{~mm}$ and wind speed varied from 0 to $5.10 \mathrm{~m} / \mathrm{s}$ (Table 1). The period of more intense pollen foraging activity was during the summer (from December to March); the mean number of foragers registered was 161.68 (S.D. \pm 115.71 ). During the winter (from June to September) we registered $19.18( \pm 16.99)$ as the mean number of foragers returning with pollen loads. Within the spring (from September to December) and autumn (from March to June), the number of foragers returning with pollen loads remained between $40.89( \pm 40.44)$ to $30.76( \pm 18.87)$, respectively. Statistical analysis showed that the pollen foraging activity in the summer was significantly more intense than in other seasons of the year: ANOVA (D.F.= 3; 846): $\mathrm{F}=246.80$, $\mathrm{P}<0.001$. Pairwise comparisons showed significant differences among different seasons (95\% C.1. of difference): Summer vs Autumn: 115.20 to $146.70, \mathrm{P}<0.001$; Summer vs Winter: 126.80 to $158.20, \mathrm{P}<0.001$; Summer vs Spring: 105.10 to $136.50, \mathrm{P}<0.001$. Foraging activity in the winter was significantly less intense than in the spring $(-37.45$ to $-5.97, \quad \mathrm{P}=0.001)$. No significant difference was registered when comparing the mean pollen foraging between spring and autumn (-25.86 to 5.61, $\mathrm{P}=0.432)$ (Figure 1). The data obtained were also submitted to statistical analysis regarding the interactions among the pollen collection and climate variables, within each season (Table 2).

A mixed linear model was fitted using all the climatic variables tested. Due to the way the model fitted data, the natural $\operatorname{logs}$ of the collected pollen was used instead. The results obtained showed that seven variables tested were statistically correlated to the pollen collection observed (ANOVA): Maximum temperature of the day $(\mathrm{P}<0.001)$, minimum temperature of the day $(\mathrm{P}=0.006)$, dew point temperature $(\mathrm{P}=$ $0.002)$, relative humidity $(\mathrm{P}=0.041)$, cloud cover $(\mathrm{P}<0.001)$, rainfall $(\mathrm{P}<0.001)$ and the date of the sample $\quad(\mathrm{P}<0.001) \quad($ Table 2; Figure 2). A predictive mathematical equation was also produced compiling all the statistically significant variables tested:

Number of worker bees returning with pollen loads $=46.5886+(0.6735 \times \mathrm{A})+(0.06861 \times \mathrm{B})$ $+(0.04815 x \mathrm{C})+(0.02959 x \mathrm{D})-(0.00381 x \mathrm{E})$ $-(0.00539 x \mathrm{~F})+(-0.00267 x \mathrm{G})$.

$A$ : Maximum temperature of the day; $B$ : Minimum temperature of the day; $C$ : Dew point temperature by the time of the observation; $D$ : Rainfall of the day; $E$ : Humidity by the time of the observation; $F$ : Cloud Cover by the time of the observation; $G$ : date of observation.

Table 1 . The climatic variables daily registered by this study

\begin{tabular}{cccccc}
\hline Variables & Measuring unit & Mean & S.D. & Max. & Min. \\
\hline Pollen foragers & $\mathrm{NWB}$ & 69.69 & 56.31 & 443.00 & 0.00 \\
Max. temperature & ${ }^{\circ} \mathrm{C}$ & 30.52 & 3.13 & 39.00 & 22.40 \\
Min. temperature & ${ }^{\circ} \mathrm{C}$ & 17.04 & 2.730 & 21.40 & 10.90 \\
Dew point temperature & ${ }^{\circ} \mathrm{C}$ & 15.59 & 3.45 & 22.00 & 6.90 \\
Air temperature & ${ }^{\circ} \mathrm{C}$ & 19.93 & 2.80 & 35.00 & 12.30 \\
Relative humidity & $\%$ & 63.99 & 31.64 & 100.00 & 22.00 \\
Height of the first base of clouds & $\mathrm{m}$ & 2655.49 & 339.02 & 2750.00 & 75.00 \\
Cloud cover & $\%$ & 47.69 & 39.69 & 100.00 & 0.00 \\
Rainfall & $\mathrm{mm}$ & 2.40 & 1.45 & 23.00 & 0.00 \\
Atmospheric pressure & $\mathrm{hPa}$ & 948.45 & 7.22 & 955.50 & 921.80 \\
Atmospheric pressure variation & $\mathrm{hPa}$ & -0.35 & 0.87 & 1.70 & -1.90 \\
Wind speed & $\mathrm{m} / \mathrm{s}$ & 2.40 & 1.45 & 5.10 & 0.00 \\
\hline
\end{tabular}

NWB: Number of worker bees returning with pollen loads on the corbicula. 
Table 2. Multiple regression of the climatic variables affecting pollen collection, within each season

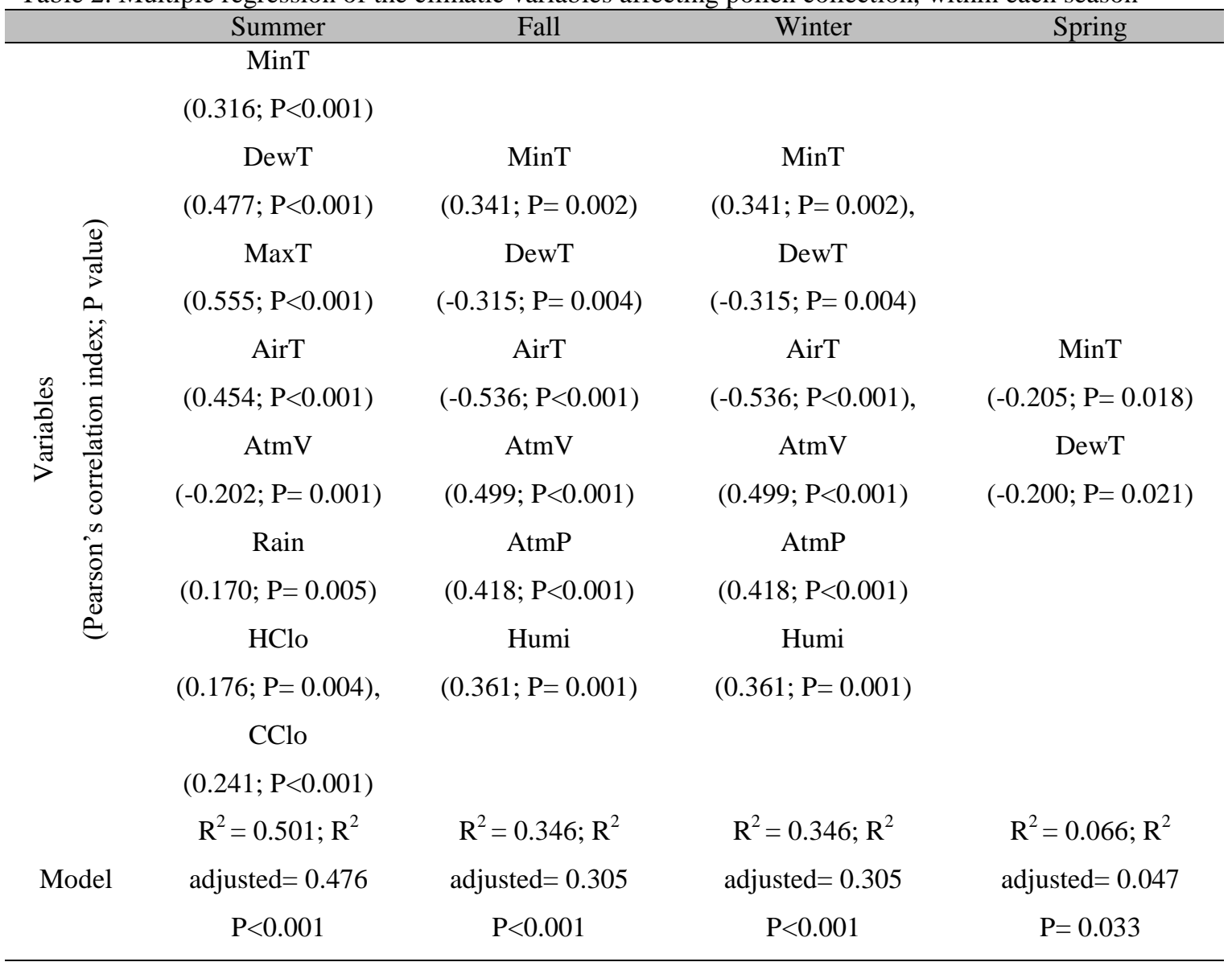

MaxT: Maximum temperature of the day; MinT: Minimum temperature of the day; DewT: Dew point temperature; AirT: Air temperature at the time of the observation; Humi: Relative humidity at the time of the observation; HClo: Height of the first base of clouds at the time of the observation; CClo: Cloud cover at the time of the observation; Rain: Rainfall (24h previous to the time of the observation); AtmP: Atmospheric pressure at the time of the observation; AtmV: Atmospheric pressure variation (three hours previous to the observation time).

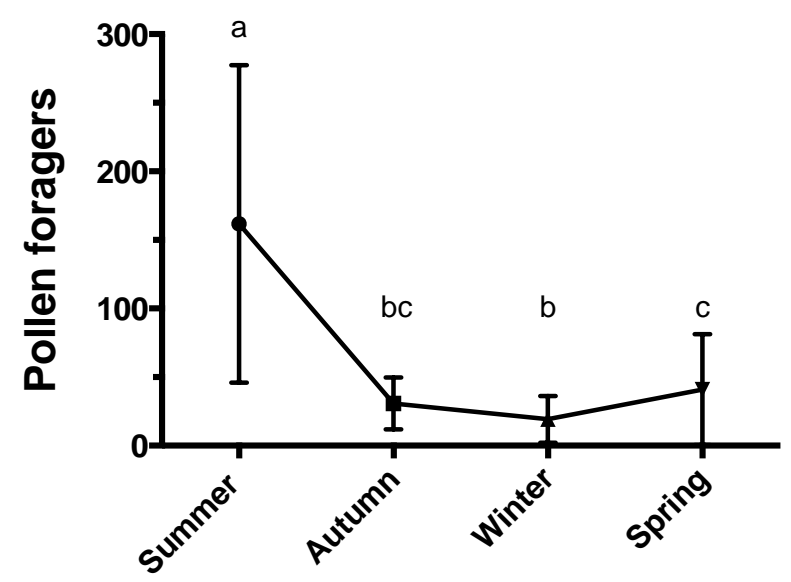

ANOVA: $\mathrm{F}=246.80 ; \mathrm{P}<0.001$

Figure 1. Pollen foraging activity among different seasons. Different letters indicate pairwise significant difference among obtained results. Superior/Inferior bars indicate Standard deviation. 
Analysis of the effects...

Table 3. ANOVA table for the linear mixed model and the significance of each climatic variable tested

\begin{tabular}{cccccc}
\hline Variables & Estimate & $\begin{array}{c}\text { Standard } \\
\text { Error }\end{array}$ & D.F. & t Value & $\operatorname{Pr}>|t|$ \\
\hline Intercept & 46.588 & 11.557 & 41 & 4.030 & $<0.001$ \\
Air temperature & 0.0231 & 0.020 & 622 & 1.130 & 0.260 \\
Atmospheric pressure & 0.0083 & 0.006 & 622 & 1.310 & 0.190 \\
Atmospheric pressure var. & -0.058 & 0.060 & 622 & -0.970 & 0.330 \\
Cloud cover & -0.005 & 0.001 & 622 & -4.590 & $<0.001$ \\
Date & -0.002 & 0.0004 & 622 & -6.070 & $<0.001$ \\
Dew point temperature & 0.048 & 0.016 & 622 & 3.010 & 0.002 \\
Height of first base of clouds & -0.0001 & 0.0001 & 622 & -1.470 & 0.142 \\
Humidity & -0.003 & 0.001 & 622 & -2.050 & 0.040 \\
Max temperature & 0.067 & 0.018 & 622 & 3.630 & $<0.001$ \\
Min temperature & 0.068 & 0.0251 & 622 & 2.730 & 0.006 \\
Rainfall & 0.029 & 0.008 & 622 & 3.550 & $<0.001$ \\
Wind speed & 0.045 & 0.032 & 622 & 1.420 & 0.156 \\
\hline
\end{tabular}

A

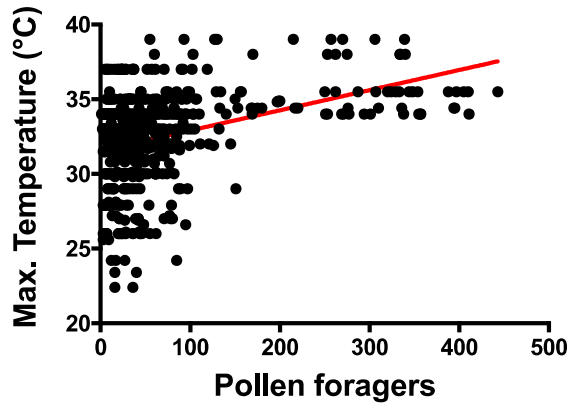

$Y=0.01337^{\star} X+31.56 ; r^{2}=0.1359$

C

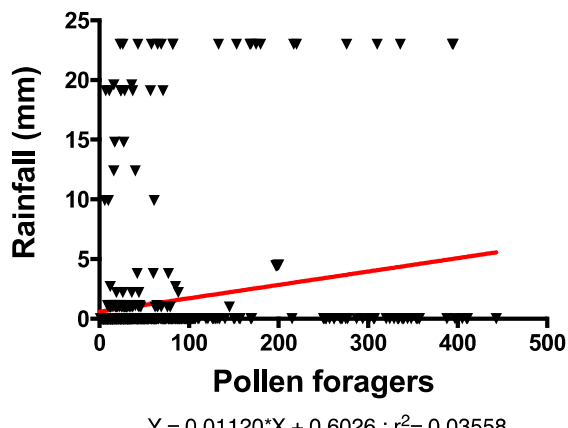

B

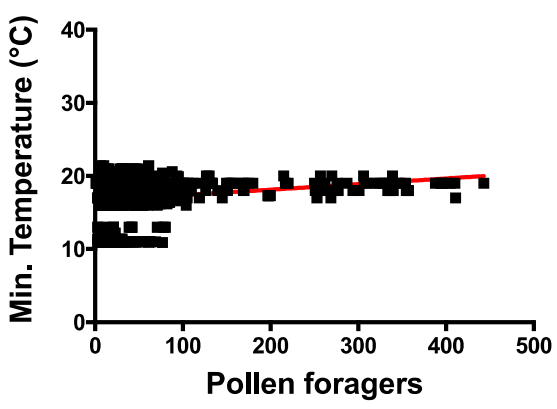

$Y=0.007646^{\star} X+16.60 ; r^{2}=0.0487$

D

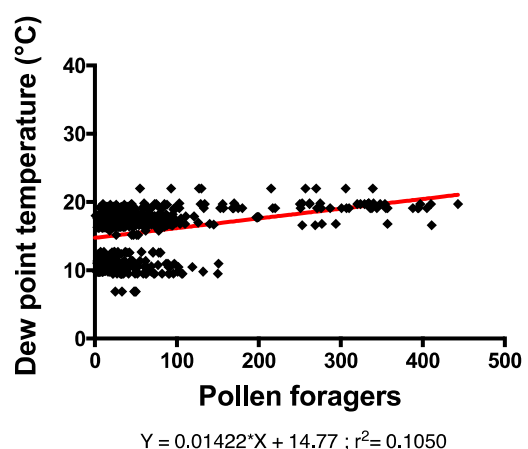

Figure 2. Linear regression between the number of foragers returning with pollen loads and the maximum (A), minimum (B), dew point temperature (C) and rainfall (D). 


\section{DISCUSSION}

The observed climate conditions significantly influenced the pollen collection. A total of seven, out of twelve climatic variables presented statistically significant relationship to variations in the number of pollen foragers. The most impacting variables were the ones related to temperature. Several authors observed a similar positive correlation between temperature and flight activity of honey bees (Vicens and Bosch, 2000; Alves et al., 2015). This positive correlation between foraging and temperature can also explain the partial loss of activity/productivity within the winter. Alves et al. (2015) and Malerbo-Souza and Silva (2011) described that the foraging activities of Africanized honey bees usually begins after the temperature reaches a threshold (around $15^{\circ} \mathrm{C}$ ). According to Polatto et al. (2014), African hybrids of $A$. mellifera present more intense activities of flower-visiting and are less susceptible to competition with other bees species, earlier in the day (7:00 to 8:00am). Temperatures below this range may be a limiting factor for the foraging of these bees during the winter. Similar results were obtained by Alves et al. (2015), which observed a more intense foraging activity of Africanized honey bees when the temperature was high (around $30^{\circ} \mathrm{C}$ ) and the relative humidity was low (around $45 \%$ ). The availability of resources during the winter can also be part of the explanation for the significantly reduced foraging activity.

When the data were analyzed separately (within seasons) we see that the climatic variables present different impact on pollen collection. During the summer, winter and fall, the proposed models could explain a significant fraction of the variability observed in the pollen collection. Although, within the spring the pollen collection seems to be less influenced by the climatic conditions (Table 2).

The surrounding campus flora comprises 289 native and introduced species distributed in 232 genera and 73 botanical families, about $67 \%$ of those plants present melittophily as the main pollination syndrome (Aleixo et al., 2014; Silva et al., 2014). Among the species present in USP campus we can find several specimens of Alternanthera brasiliana, Chamissoa altissima (Amaranthaceae); Bidens sulphurea, Crepis japonica, Montanoa bipinnatifida, Sphagneticola trilobata, Tithonia diversifolia (Asteraceae); Eucalyptus citriodora, E. grandis, E. moluccana, Eugenia brasiliensis, E. involucrate, $E$. pyriformis, E. uniflora, Syzygium cumini, S. malaccense (Myrtaceae); Paspalum notatum and Brachiaria sp (Poaceae); Citrus latifolia, $C$. limonia, Murraya paniculata (Rutaceae) (Silva et al., 2014). According to Almeida-Anacleto et al. (2012) species of the Amaranthaceae, Araliaceae, Asteraceae, Myrtaceae, Poaceae and Rutaceae families are important sources of pollen for A. mellifera in São Paulo State. Barreto et al. (2006), assert that in the São Paulo State there is more pollen available for bees, in the environment, within periods between January and May, as well as between September and December. This research didn't register the vegetal species producing pollen and the anthesis patterns presented by the flora of the studied area. Although, researches have been showing a flowering peak starting at the transition between the dry and the rainy season (September), in the area (Aleixo et al., 2014). The authors report that the average peak of pollen availability corresponds to February, revealing a seasonal pattern mainly related to the rainy season. Aleixo et al. (2014) also highlight that during the dry season species from the genus Eucalyptus and Eugenia are an important pollen sources, whereas during the rainy season several species contributed for pollen availability: Cestrum nocturnum, Ludwigia elegans, Ricinus communis, Bidens sulphurea, Dichorisandra thyrsiflora, Galinsoga parviflora, Sida rhombifolia, Solanum violaefolium, Sphagneticola trilobata, Tradescantia pallid, Chamissoa altissima, Cissus verticillata, Momordica charantia and Solanum seaforthianum (Aleixo et al., 2014).

In this research, the relative humidity was also related to the foraging activity of the tested bees. This climatic variable was extensively studied and seems to be negatively correlated to foraging (Polatto et al., 2014). Alves et al. (2015) observed that when the humidity was above $81 \%$, there was no foraging activity for Africanized honey bees. It is also considered that high humidity levels can affect sugar concentration in nectar, as well as pollen physical properties (Silva et al., 2013; Alves et al., 2015), thus hampering pollen collection by foragers. Other Apis species seems to present the 
same patterns of foraging according to the relative humidity intensity. Reddy et al. (2015) observed an intense decrease in the activity of $A$. cerana pollen foragers when humidity increased in tropical India. According to the authors, rainfall is closely related to humidity, higher humidity conditions frequently being registered just before, during or just after rainfalls. As rainfall makes foraging activities more difficult and potentially risky, the humidity and the cloud cover tends to present a negative pressure on the flying activity and consequently the pollen foraging.

The results obtained in this research show a low but significant positive relationship between pollen foraging and rainfall. This positive statistical relationship may be explained by the characteristics of the two distinguished seasons found in the region where the data were collected. The dry period (from April to September) coincides with cooler temperature (in which the bee's activity tends to be reduced) and the rainy season coincides with higher temperatures rates and blooming (according to Barreto et al., 2006). It is also important to highlight that the rainfall data used in this research was relative to a period of 24 hours prior to the observation and it is not referent to the exact moment in which the observation was performed.

The cloud cover is generally inversely proportional to solar radiation. We observed a statistically significant negative relationship between cloud cover and pollen foraging, which seems to be in accordance to Vicens and Bosch (2000). The authors observed that A. mellifera is fully active at solar radiation higher than $300 \mathrm{w} / \mathrm{m}^{2}$, being particularly sensitive to drops in solar incidence below this threshold. Further studies are still necessary to evaluate the effects of luminosity on bee pollen production. Moura and Pegoraro (2006); and Polatto et al. (2014) also describe a significant influence of sunlight incidence on pollen foraging/production by Africanized honey bees.

Vicens and Bosch (2000) assert that the wind, even at favorable temperatures and light intensity, may cause foraging activity to cease. The results obtained in this research showed a positive relationship of pollen collection and wind speed (0.045) but not statistically significant $(\mathrm{P}=0.156)$. The narrow range of different wind speeds registered (from 0.0 to $5.1 \mathrm{~m} / \mathrm{s}$ ) in the region may be a possible explanation for this lack of statistical consistency. More studies are necessary for a definitive conclusion on the effects of wind speed on pollen foraging.

\section{CONCLUSION}

This research brings information to help the development of a more effective pollen productive system. Our data highlight the significant influence of climate variables on foraging behavior. Thus, beekeepers should be attentive to climate conditions of the regions in which their apiaries are settled to provide suitable conditions for pollen harvesting. We conclude that regions in which temperature range is narrow, rainfall is not scarce (but regularly divided among seasons), the relative humidity is not constantly high and present high solar incidence can be considered more suitable for bee pollen production.

\section{ACKNOWLEDGEMENTS}

The authors thank CNPq (Conselho Nacional de Desenvolvimento científico e tecnológico) for financial assistance. We also thank Dr. Emily Griffith (North Carolina State University Statistics Department) for all the help with the statistics.

\section{REFERENCES}

ALEIXO, K.P.; FARIA, L.B.; GROPPO, M.; CASTRO, M.M.N.; SILVA, C.I. Spatiotemporal distribution of floral resources in a Brazilian city: Implications for the maintenance of pollinators, especially bees. Urban For. Urban Green., v.13, p.689-696, 2014.

ALMEIDA-ANACLETO, D.; MARCHINI, L.C.; CAMARGO, A.C.; MORETI, C.; SOUZA, V.C. Plants used by bees as pollen sources in the Brazilian "Cerrado". Sociobiology, v.59, p.14831494, 2012.

ALVES, L.H.S.; CASSINO, P.C.R.; PREZOTO, F. Effects of abiotic factors on the foraging activity of Apis mellifera Linnaeus, 1758 in inflorescences of Vernonia polyanthes Less (Asteraceae). Acta Sci. Anim. Sci., v.37, p.405, 2015. 
BARRETO, L.M.R.C.; FUNARII, S.R.C.; ORSI, R.O.; DIB, A.P. Produção de pólen no Brasil. Taubaté, SP: Cabral Editora Universitaria, 2006. BROWN, M.J.F.; PAXTON, R.J. The Conservation of bees: a global perspective. Apidologie, v.40, p.410-416, 2009.

CAMPOS, M.G.R.; FRIGERIO, C.; LOPES, J.; BOGDANOV, S. What is the future of BeePollen? J. ApiProd. ApiMed. Sci., v.2, p.131-144, 2010.

CVITKOVI, D.; GRGI, Z.; MATAŠIN, Ž.; PAVLAK, M.; FILIPI, J.; GAJGER, I.T. Economic aspects of beekeeping production in Croatia. Vet. Arh., v.79, p.397-408, 2009.

DANKA, R.G.; BEAMAN, L.D. Flight activity of USDA-ARS Russian honey bees (Hymenoptera: Apidae) during pollination of lowbush blueberries in Maine. J. Econ. Entomol., v.100, p.267-272, 2007.

De MATTOS, I.M.; SOUZA, J.E.E.; SOARES, A. Analysis of the effects of colony population size and feeding supplementation on bee pollen production. J. Apic. Res., v.54, p.411-419, 2016.

FAO - Food and Agriculture Organization of the United Nations. Bees and their role in forest livelihoods: A guide to the services provided by bees and the sustainable harvesting, processing and marketing of their products, by Nicola Bradbear, Non-wood forest products, 19, Rome, Italy, 2009.

FAO STATISTICS DIVISION. FAOSTAT. Disponível em: <http://www.fao.org/faostat/ en/\#home>. Acesso em: 1 mar. 2017.

GALLAI, N.; SALLES, J.-M.; SETTELE, J.; VAISSIÈRE, B. E. Economic valuation of the vulnerability of world agriculture confronted with pollinator decline. Ecol. Econ., v.68, p.810821, 2009.

KEARNS, C.A.; INOUYE, D.W.; WASER, N.M. ENDANGERED MUTUALISMS: The conservation of plant-pollinator interactions. Ann. Rev. Ecol. Syst., v.29, p.83-112, 1998.

KOFFLER, S.; MENEZES, C.; MENEZES, P.R. et al. Temporal variation in honey production by the stingless bee Melipona subnitida (Hymenoptera: Apidae): Long-term management reveals its potential as a commercial species in Northeastern Brazil. J. Econ. Entomol., v.108, p.858-867, 2015.
KÖPPEN, W.; GEIGER, R. Klimate der Erde, Justus Perthes Gotha. 1928

MALERBO-SOUZA, D.T.; SILVA, F.A.S. Comportamento forrageiro da abelha africanizada Apis mellifera L. no decorrer do ano. Acta Sci. Anim. Sci., v.33, p.183-190, 2011.

MOURA, J.; PEGORARO, A. Production of bee pollen using pollen collectors in the timetable of food availability in the top of Bracatinga's bloom (Mimosa scabrella). Sci. Agrar., v.7, p.97-100, 2006.

POLATTO, L.P.; CHAUD-NETTO, J.; ALVESJUNIOR, V.V. Influence of abiotic factors and floral resource availability on daily foraging activity of bees: influence of abiotic and biotic factors on bees. J. Insect Behav., v.27, p.593612, 2014.

REDDY, P.V.; RASHIMI, T.; VERGHESE, A. Foraging activity of Indian honey bee, Apis cerana in relation to ambient climate variables under tropical conditions. J. Environ. Biol., v.36, p.537-542, 2015.

SAS user guide. Cary:SAS Institute, 2004.

SILVA, C.I.; IMPERATRIZ-FONSECA, V.L.; GROPPO, M. et al. Catálogo polínico das plantas usadas por abelhas no campus da USP de Ribeirão Preto. Ribeirão Preto, SP: Holos Editora, 2014.

SILVA, K.N.; DUTRA, J.C.S.; NUCCI, M.; POLATTO, L.P. influência dos fatores ambientais e da quantidade de néctar na atividade de forrageio de abelhas em flores de Adenocalymma bracteatum (Cham.) DC. (Bignoniaceae). EntomoBrasilis, 2013. Disponível em: <http://www.periodico.ebras.bio.br/ojs/index.php /ebras/article/view/ebrasilis.v6i3.295>. Acessado em: 13 abr. 2016.

TOOKE, F.; BATTEY, N.H. Temperate flowering phenology. J. Exp. Botany, v.61, p.2853-2862, 2010.

VICENS, N.; BOSCH, J. Weather-dependent pollinator activity in an apple orchard, with special reference to osmia cornuta and Apis mellifera (Hymenoptera: Megachilidae and apidae). Environ. Entomol., v.29, p.413-420, 2000. 